\title{
Chemical Composition and Antimicrobial Efficiency of Swietenia macrophylla Seed Extract on Clinical Wound Pathogens
}

\author{
Hanan Kumar Gopalan¹, Nor Faizzah Md Hanafiah'², Leong Chean Ring², Wen-Nee Tan², \\ Suzana Wahidin ${ }^{2}$, Teo Siew Hway ${ }^{2}$, and Tong Woei Yenn ${ }^{2, *}$ \\ ${ }^{1}$ Universiti Kuala Lumpur, Institute of Medical Science Technology, A1-1, Jalan TKS 1, \\ Taman Kajang Sentral, Selangor, 43000 Kajang, Selangor \\ ${ }^{2}$ Universiti Kuala Lumpur, Malaysian Institute of Chemical and Bioengineering Technology, \\ Lot 1988 Kawasan Perindustrian Bandar Vendor, Taboh Naning, Alor Gajah, Melaka, Malaysia \\ ${ }^{3}$ School of Distance Education, Universiti Sains Malaysia, 11800 Minden, Penang, Malaysia
}

\begin{abstract}
Microbial wound infection prolonged the hospitalization and increase the cost for wound management. Silver is commonly used as antimicrobial wound dressing. However, it causes several adverse side effects. Hence, this study was aimed to evaluate the antimicrobial efficiency of Swietenia macrophylla seed extract on clinical wound pathogens. Besides, the bioactive constituents of the seed extract were also determined. $S$. macrophylla seeds were extracted with methanol by maceration method. The seed extract inhibited 5 test bacteria and 1 yeast on disc diffusion assay. The antibacterial activity was broad spectrum, as the extract inhibited both Gram positive and Gram negative bacteria. On kill curve analysis, the antibacterial activity of the seed extract was concentration-dependent, the increase of extract concentration resulted in more reduction of bacterial growth. The extract also caused $99.9 \%$ growth reduction of Bacillus subtilis relative to control. A total of 21 compounds were detected in gas chromatography- mass spectrometry analysis. The predominant compounds present in the extract were oleic acid (18.56\%) and linoleic acid (17.72\%). In conclusion, the methanolic extract of $S$. macrophylla seeds exhibited significant antimicrobial activity on clinical wound pathogens. Further investigations should be conducted to purify other bioactive compounds from the seeds of $S$. macrophylla.

Keywords - Swietenia macrophylla, seed extract, chemical composition, antimicrobial activity
\end{abstract}

\section{Introduction}

The wound is a breakdown of cellular and tissue continuity. It is caused by any sudden cut or accident due to chemical, physical, thermal or any immunological exploitation to the tissue. ${ }^{1}$ The exposure of wound to the surrounding provides warm, moist and nutritious environment for the microbial colonization and proliferation. This will eventually lead to hypoxic, ischemic and necrotic of the tissues. ${ }^{2}$ Besides, microbial wound infection also prolonged the hospitalization and increase the cost for the wound management. Thus, antimicrobial agents are frequently applied for the treatment of clinical wound infections.

Silver ions are widely used in wound dressing products

\footnotetext{
*Author for correspondence

Tong Woei Yenn, Universiti Kuala Lumpur, Malaysian Institute of Chemical and Bioengineering Technology, Lot 1988 Kawasan Perindustrian Bandar Vendor, Taboh Naning, Alor Gajah, Melaka, Malaysia

Tel: +606-5512000; E-mail: wytong@unikl.edu.my
}

to prevent wound infections. ${ }^{3}$ It inhibits microbial growth by denaturing its DNA. However, some adverse side effects were reported on silver wound dressing. Permanent bluish-grey discoloration known as argyria of the skin might occur due to chronic exposure to the silver. The chronic exposure to silver also causes complications such liver and kidney damage, irritation to eye, skin, and respiratory tract. Besides, silver dressing also triggers allergic response on some patients. ${ }^{4}$ Hence, a new naturalbased antimicrobial dressing is necessary to replace silver ions, Thus, this study was aimed to evaluate the antimicrobial efficiency of Swietenia macrophylla seed extract on clinical wound pathogens. Besides, the bioactive constituents of the seed extract were determined via gas chromatography - mass spectrometry (GC/MS) analysis.

S. macrophylla is commonly known as Mahogany in Asian countries. S. macrophylla is classified as magnoliopsia which belongs to Meliaceae family. ${ }^{5}$ The tree is about 30 $\mathrm{m}$ tall and $100-200 \mathrm{~cm}$ at breast height and its fruit seems to point upwards to the sky. The bark is entirely 
dark red-brown in colour and it is used traditionally to dye cotton threads. ${ }^{6} S$. macrophylla is commonly used in Asian folk medicine as pain reliever and the treatment of infectious diseases. The seeds of the plant were used to treat hypertension and diabetes, where the fruits were used to improve blood circulation and skin conditions. ${ }^{6}$ Paritala et al. showed that $S$. macrophylla displayed high antimalarial activity, both in vivo and in vitro. ${ }^{7}$ Besides, the antioxidant activity of the leaves was also reported. ${ }^{8}$

\section{Experimental}

Extraction of $\boldsymbol{S}$. macrophylla seeds $-S$. macrophylla seeds were collected from Sungai Petani, Kedah, Malaysia. In the laboratory, the seeds were washed under running tap water and dried at $50^{\circ} \mathrm{C}$ for 3 days. The seeds were crushed in an electric grinder (Panasonic) to coarse powder form. The extraction was done by maceration method. The powdered material was soaked in methanol at a ratio 1:5 (w/v) for 24 hours. The extract was filtered with Whatman No 1 filter paper and the filtrate was concentrated under reduced pressure using rotary evaporator fitted with vacuum pump at $60{ }^{\circ} \mathrm{C}$. The concentrated extract was then dried at $50^{\circ} \mathrm{C}$, until a dry paste was obtained.

Test microorganisms - The test microorganisms were provided by Upstream Bioprocess Laboratory, Universiti Kuala Lumpur. The test microorganisms used in this study included 4 Gram-positive bacteria (Staphylococcus aureus, Bacillus cereus, Bacillus subtilis and methicillinresistant $S$. aureus [MRSA]), 6 Gram-negative bacteria (Proteus mirabilis, Yersinia sp., Escherichia coli, Klebsiella pneumoniae, Shigella boydii and Acinobacter anitratus), 3 fungal species (Aspergillus niger, Microsporum fulvum and Rhizopus sp.), 1 yeast (Candida utilis). The microbial strains were previously isolated from patients with chronic diabetic wounds in Hospital Seberang Jaya. The bacterial and yeast suspensions were adjusted to match the turbidity of $0.5 \mathrm{McF}$ arland standard (approximately $1 \times 10^{8} \mathrm{CFU} / \mathrm{ml}$ ). The density of fungal suspension was counted with haemocytometer (Neubauer) under light microscope and adjusted to approximately $4 \times 10^{5}$ spores $/ \mathrm{ml}$.

Disc diffusion assay - The antimicrobial activity of the extract was tested as per protocols described by Tong et al. with modifications. ${ }^{9}$ Mueller Hinton agar (Merck) was used for test bacteria and yeast, and potato dextrose agar (Oxoid) was used for fungi. The seed extract was prepared at concentration $100 \mathrm{mg} / \mathrm{ml}$ by dissolving the extract in methanol. Firstly, the microbial inoculum was streaked on the agar plate by using sterile cotton swab.
Then, a sterile Whatman paper disc (6 $\mathrm{mm}$ in diameter) impregnated with $20 \mu \mathrm{L}$ of the extract was placed on the surface of inoculated medium. Then, $20 \mu \mathrm{L}$ of $25 \mu \mathrm{g} / \mathrm{ml}$ Chloramphenicol was used as positive control and $20 \mu \mathrm{L}$ of methanol served as negative control. The plates were incubated at $37^{\circ} \mathrm{C}$ for 24 hours (bacteria and yeasts) and $30{ }^{\circ} \mathrm{C}$ for 72 hours for test fungi. After the incubation, the diameters of clear zones surrounding the paper discs were measured. The experiment was done in triplicate and the diameter of clear zone was expressed in average diameter \pm standard deviation.

Broth microdilution assay - The test microorganisms susceptible to the seed extract were chosen for this assay. The assay was performed in sterile flat bottom 96 wells plate (Nest). A serial two-fold dilution was performed to dilute the seed extract with double strength Mueller Hinton broth (Merck). To achieve a final volume of 200 $\mu \mathrm{L}$ in each well, $100 \mu \mathrm{L}$ of extract was added with $100 \mu \mathrm{L}$ of microbial suspension. The final concentration of the seed extract ranged from 25.00 to $0.20 \mathrm{mg} / \mathrm{ml}$. Sterility control was prepared by replacing the microbial suspension with sterile distilled water (one for each extract concentration), and the growth control was included by replacing the extract with methanol. After 24 hours of incubation at $37^{\circ} \mathrm{C}$, the minimal inhibitory concentration (MIC) was determined by measuring the absorbance of each well with a microplate reader at $600 \mathrm{~nm}$ (Varioskan LUX). The sterility control was used as blank. The MIC was recorded as the lowest concentration of extract that prevent microbial growth (same turbidity with blank). To determine the minimal bactericidal concentration (MBC), the sample from each well was suitably streaked on Mueller Hinton agar plate. After 24 hours of incubation at $37^{\circ} \mathrm{C}$, the viability of the test microorganism was observed. The MBC was determined as the lowest concentration of extract to kill the test microorganism.

Kill curve study - The study was conducted according to the protocol defined by Tong et al. ${ }^{9}$ B. subtilis was selected as it showed the lowest MIC on broth microdilution assay. Firstly, $1 \mathrm{ml}$ of microbial inoculum was added into $20 \mathrm{ml}$ of sterile Mueller Hinton broth. To achieve the final volume of $25 \mathrm{ml}, 4 \mathrm{ml}$ of extract was added. The extract was tested at 3 different concentrations: MIC, MBC and twice the MBC. Methanol was used as negative control. All the flasks were incubated at $37^{\circ} \mathrm{C}$ with rotational speed of $120 \mathrm{rpm}$. In every 6 hours, $1 \mathrm{ml}$ of the sample was withdrawn. The viable cell count was performed to enumerate the living bacterial cells in the sample. The sample was suitably diluted and plated on Mueller Hinton agar. The kill curves were plotted as logarithm of the 
number of viable cells versus incubation time.

Column chromatography - A glass column of $22 \mathrm{~mm}$ diameter and $44 \mathrm{~cm}$ in length was used in vertical position. Hexane and ethyl acetate at a ratio of $1: 1(\mathrm{v} / \mathrm{v})$ was used as mobile phase. To pack the column, $25 \mathrm{~g}$ of silica gel 60 with the size of $40-63 \mu \mathrm{m}$ (Merck) was dissolved in mobile phase and poured into the column. The column was left for overnight. On the following day, $100 \mu \mathrm{g}$ of seed extract was loaded into the column. To run the column in isocratic mode, the mobile phase was added into the column from time to time. The fractions were collected based on the band colour. Then, the separated fractions were dried at $50{ }^{\circ} \mathrm{C}$. All fractions collected were subjected to disc diffusion assay to test the antimicrobial activity on B. subtilis (Section 2.3). The fraction that showed significant inhibitory activity on $B$. subtilis will be chosen for GC/MS analysis.

Gas chromatography-mass spectrometry analysis The GC/MS analysis was performed using an Agilent Technologies 7890A equipped with mass spectrometer (Agilent Technologies 5975C inert XL MSD with Triple Axis Detector). HP-5 MS column (Agilent Technologies Inc., Santa Clara, CA), (5\%-phenyl)-methylpolysiloxane, $30 \mathrm{~m} \times 0.25 \mathrm{~mm}$ i.d., film thickness, $0.25 \mu \mathrm{m}$ was employed. The operating conditions of the column were as follows: initial oven temperature, $100{ }^{\circ} \mathrm{C}$ for $1 \mathrm{~min}$, then to $250^{\circ} \mathrm{C}$ at $5{ }^{\circ} \mathrm{C} / \mathrm{min}$ and held for $5 \mathrm{~min}$; injector port, $260^{\circ} \mathrm{C}$; detector temperatures, $280^{\circ} \mathrm{C}$; carrier gas, $1.0 \mathrm{~mL} / \mathrm{min}$ Helium; injection volume, $1.0 \mu \mathrm{L}$; split ratio, 50:1. The detected compounds were identified by direct comparison of their mass spectra with NIST 08 Library.

\section{Results and Discussion}

In this study, the bioactive compounds of S. macrophylla seeds were extracted using maceration method. Maceration is an efficient extraction method for seed sample as it mechanically breaks the seed coats, in order to release the bioactive compounds from the seed. ${ }^{10}$ Besides, the $S$. macrophylla seeds were powdered to improve the extraction efficiency by increasing the surface area exposed to the extraction solvent. We utilized methanol as extraction solvent in this study, as Onivogui et al. reported that methanolic extract of Anisophyllea laurina seeds exhibited better antioxidant and antimicrobial activities. ${ }^{11}$

The antimicrobial activity of the seed extract was tested on disc diffusion assay. Out of 14 test microorganisms, 5 bacteria and 1 yeast were susceptible to the extract (Table 1). The largest inhibition zone was recorded on Acinobacter anitratus, with a zone size of $16 \mathrm{~mm}$. The antibacterial

Table 1. Antimicrobial activity of S. macrophylla seed extract on wound microorganisms.

\begin{tabular}{|c|c|c|c|}
\hline \multirow[t]{2}{*}{ Test microorganisms } & \multicolumn{3}{|c|}{ Diameter of zone (mm) } \\
\hline & $\begin{array}{l}\text { Seed } \\
\text { extract }\end{array}$ & $\begin{array}{l}\text { Chloramphenicol } \\
\text { (Positive control) }\end{array}$ & $\begin{array}{c}\text { Methanol } \\
\text { (Negative control) }\end{array}$ \\
\hline \multicolumn{4}{|l|}{ Gram Positive Bacteria } \\
\hline S. aureus & $13.0 \pm 0.6$ & $12.0 \pm 0.6$ & - \\
\hline B. cereus & $15.0 \pm 0.6$ & $16.0 \pm 1.0$ & - \\
\hline B. subtilis & $15.0 \pm 1.5$ & $16.0 \pm 0.6$ & - \\
\hline MRSA & - & $22.0 \pm 0.6$ & - \\
\hline \multicolumn{4}{|l|}{ Gram Negative Bacteria } \\
\hline P. mirabilis & - & $14.0 \pm 0.6$ & - \\
\hline Yersinia sp. & - & $18.0 \pm 0.6$ & - \\
\hline E. coli & - & $11.0 \pm 0.6$ & - \\
\hline K. pneumoniae & - & $20.0 \pm 0.6$ & - \\
\hline S. boydii & $15.0 \pm 1.0$ & $15.0 \pm 1.0$ & - \\
\hline A. anitratus & $16.0 \pm 1.2$ & $15.0 \pm 0.6$ & - \\
\hline \multicolumn{4}{|l|}{ Fungi } \\
\hline A. niger & - & - & - \\
\hline M. fulvum & - & - & - \\
\hline Rhizopus sp. & - & - & - \\
\hline \multicolumn{4}{|l|}{ Yeast } \\
\hline C. utilis & $10.0 \pm 1.2$ & $14.0 \pm 0.6$ & - \\
\hline
\end{tabular}

$(-)=$ No inhibitory activity. 
Table 2. The MIC and MBC of S. macrophylla seed extract on various clinical wound pathogens recorded on broth microdilution assay.

\begin{tabular}{ccc}
\hline \hline Tested microorganisms & MIC $(\mathrm{mg} / \mathrm{ml})$ & MBC $(\mathrm{mg} / \mathrm{ml})$ \\
\hline B. cereus & 3.13 & 6.25 \\
S. aureus & 6.25 & 25.00 \\
B.subtilis & 1.56 & 3.13 \\
S. boydii & 12.50 & 25.00 \\
A. anitratus & 12.50 & 25.00 \\
C. utilis & 12.50 & 25.00 \\
\hline
\end{tabular}

activity was broad spectrum, as the extract inhibited both Gram positive and Gram negative bacteria. However, the seed extract works better on Gram positive bacteria, where 3 out of 4 Gram positive bacteria were inhibited by the extract. Besides, no clear zones were observed on all negative controls (methanol), this indicates that the emergence of the clear zones were due to the bioactive compounds in the extract. No test fungi were inhibited by S. macrophylla seed extract. Fungi are generally more resistant to the antimicrobial compounds, because they possess thick cell wall consisting glucan and chitin which restricts the penetration of antimicrobial compounds. ${ }^{12}$

The quantitative analysis of antimicrobial susceptibility was determined on broth microdilution assay. The lowest MIC and MBC was recorded on B. subtilis (Table 2). The results obtained were consistent with disc diffusion assay, where the Gram positive bacteria were more susceptible to the seed extract. Significantly higher MBCs were recorded on both Gram negative bacteria, which is 25.00 $\mathrm{mg} / \mathrm{ml}$ for both $S$. boydii and A. anitratus. The outer membrane of Gram negative bacteria limits the penetration of antimicrobial compounds across the cell wall, which make them more resistant to the compounds. The same observation was reported by Rad et al. for Salicornia herbaceae seed extract. ${ }^{3}$ The MBCs of the seed extract were ranged from 3.13 to $25.00 \mathrm{mg} / \mathrm{ml}$. The wide range of MBCs indicates the different susceptibility of test bacteria to the extract. Based on the results, the S. macrophylla seed extract exhibited microbicidal effect on all test microorganisms. However, the MBCs recorded were significantly higher than the MICs for all test microorganism. The antimicrobial efficiency of the extract depends on the extract concentration, where a higher concentration of extract was required to exhibit killing effect on test microorganisms.

Time kill study provides essential information on the killing kinetics of the seed extract. Fig. 1 shows the kill curves of the B. subtilis. The control kill curve showed distinct $\log$ and stationary phase. The bacterial count was

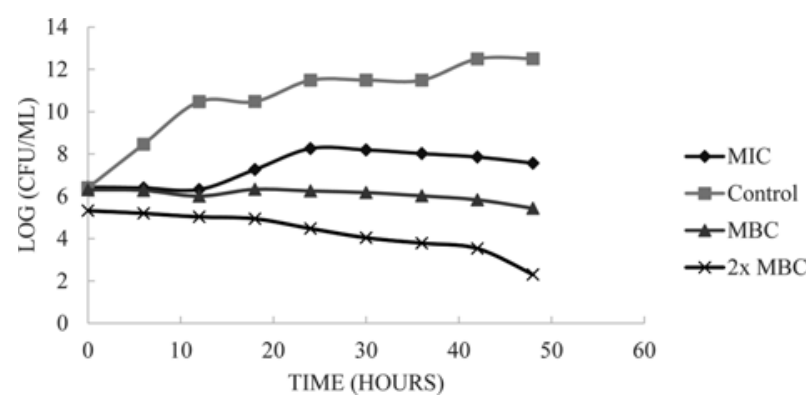

Fig. 1. The kill curves of B. subtilis when exposed to different concentrations of $S$. macrophylla seed extracts. The antibacterial activity of the extract was concentration-dependent.

significantly higher than other cultures added with seed extract. Methanol did not exhibit any inhibitory effect on the growth of $B$. subtilis. In general, the antibacterial activity of the seed extract was concentration-dependent, the increase of extract concentration resulted in the reduction of bacterial growth. The MIC kill curve showed a short log phase. Mirroring the results of broth microdilution assay, the extract concentration of MIC did not cause $99.9 \%$ of bacterial growth reduction after 24 hours of incubation. However, at concentration of MBC and twice MBC, $\log$ phase was not detected. The seed extract at these concentrations reduced the bacterial growth by $99.9 \%$ relative to control, after 6 hours of incubation. A significant death phase was detected at the end of incubation period, for concentration twice MBC. The results showed that the seed extract of $S$. macrophylla exhibited significant bactericidal effect on $B$. subtilis. Bacillus is the major isolate from wound biopsies, the results showed the potential use of $S$. macrophylla seed extract in combating Bacillus infection on wound. ${ }^{13}$

S. macrophylla seed extract was fractionated on column chromatography. The mixture of hexane and ethyl acetate was frequently used as mobile phase for the fractionation of seed extract. ${ }^{14}$ In this study, a total of 4 fractions were collected based on the band color. The first and third fractions were yellow in color, whereas the second and fourth fractions were colorless. The different interaction of the silica and the compound resulting variances rate of molecule migrate through the column. The relative rates of these movements depend on the relative strengths of the attraction of these compounds to the silica gel and upon their solubility in the solvent. All fractions collected were subjected to disc diffusion assay to test the antibacterial activity on $B$. subtilis. Only Fraction 1 showed significant inhibitory activity on $B$. subtilis, with clear zone size of $13.2 \mathrm{~mm}$.

GC/MS was employed to determine the bioactive 
Table 3. The GC/MS analysis showed the presence of 21 compounds in the Fraction 1 from methanolic extract of $S$. macrophylla seeds.

\begin{tabular}{|c|c|c|c|c|}
\hline No. & $\mathrm{RT}(\mathrm{min})$ & Compounds & PubChem ID & Area $(\%)$ \\
\hline 1 & 9.049 & (Z)-3-Tetradecene & 5362709 & 0.65 \\
\hline 2 & 11.773 & 2,4-Di-tert-butylphenol & 528937 & 0.27 \\
\hline 3 & 13.444 & 1-Hexadecene & 12395 & 1.88 \\
\hline 4 & 16.596 & 3-Hydroxy-4-(1-oxopropyl)- phenyl acetate & 448214 & 0.51 \\
\hline 5 & 17.701 & 1-Octadecene & 8217 & 2.54 \\
\hline 6 & 20.373 & Methyl hexadecanoate & 8181 & 1.35 \\
\hline 7 & 21.197 & Hexadecanoic acid & 985 & 7.00 \\
\hline 8 & 21.643 & $(E)$-5-Eicosene & 5364600 & 2.50 \\
\hline 9 & 23.532 & Methyl $(Z, Z)-9,12$-octadecadienoate & 5284421 & 2.60 \\
\hline 10 & 23.646 & Methyl (E)-9-octadecenoate & 5280590 & 3.34 \\
\hline 11 & 24.109 & Methyl octadecanoate & 8201 & 1.10 \\
\hline 12 & 24.447 & $(Z, Z)-9,12$-Octadecadienoic acid & 3931 & 17.72 \\
\hline 13 & 24.55 & (E)-9-Octadecenoic acid & 965 & 18.56 \\
\hline 14 & 24.888 & Methyl 2-hydroxyhexadecanoate & 530317 & 8.19 \\
\hline 15 & 25.271 & 1-Docosene & 74138 & 2.20 \\
\hline 16 & 26.656 & 2,6-Bis-(dimethylethyl)-4-methylphenyl 1-methylcyclopropanecarboxylate & & 5.11 \\
\hline 17 & 27.789 & 1-O-hexyl 2-O-(5-methyl-2-propan-2-ylcyclohexyl) oxalate & - & 2.49 \\
\hline 18 & 28.601 & Cyclotetracosane & 520449 & 1.09 \\
\hline 19 & 31.714 & 1-Hexacosene & & 0.53 \\
\hline 20 & 33.568 & (9Z,12Z)-1,3-Dihydroxypropan-2-yl octadeca-9,12-dienoate & 5365676 & 10.98 \\
\hline 21 & 36.744 & Hexyl 4-methylbenzoate & 230182 & 1.02 \\
\hline
\end{tabular}

constituents in Fraction 1 collected from column chromatography. Table 3 shows the bioactive principles with retention time, peak area $(\%)$, molecular formula and PubChem ID. A total of 21 compounds were detected in Fraction 1. The predominant compounds were $(E)-9$ octadecenoic acid (18.56\%) and (Z,Z)-9,12-octadecadienoic acid $(17.72 \%)$. It is interesting to note that a total of 7 derivatives of octadecene were reported in the analysis, which comprised of $57.49 \%$ based on the area in chromatogram. The seed extract of S. macrophylla was rich in fatty acids. 9-octadecenoic acid, or commonly known as oleic acid is a fatty acid that occurs in many animal fats and vegetable oils. ${ }^{15}$ It is commonly used as food additives. The antimicrobial activity of oleic acid was previously reported by Ertas et al. ${ }^{15}$ Oleic acid also used to load antibiotics in the form of liposome to combat multidrug-resistant Pseudomonas aeruginosa. ${ }^{16}$ 9,12Octadecadienoic acid, or commonly known as linoleic acid is an unsaturated fatty acid found in plant. It is used in the biosynthesis of prostaglandins and cell membrane. The antimicrobial activity of linoleic acid was previously reported by Adesanwo et al. ${ }^{17}$

In conclusion, the methanolic extract of $S$. macrophylla seeds exhibited significant antimicrobial activity on clinical wound pathogens. The extract exhibited broad spectrum antibacterial activity. Based on the GC/MS analysis, oleic acid and linoleic acid were the main components present in the bioactive fraction. Further investigations should be conducted to purify other bioactive compounds from the seeds of $S$. macrophylla.

\section{Acknowledgements}

The authors are thankful to Universiti Kuala Lumpur (str17003).

\section{References}

(1) Bowler, P. G.; Duerden, B. I.; Armstrong, D. G. Clin. Microbiol. Rev. 2001, 14, 244-269.

(2) Abeysinghe, P. D.; Weeraddana, C. S. J. Pharm. Biomed. Sci. 2011, $11,1-4$.

(3) Rai, M. K.; Deshmukh, S. D.; Ingle, A. P.; Gade, A. K. J. Appl. Microbiol. 2012, 112, 841-852.

(4) Panyala, N. R.; Pena-Mendez, E. M.; Havel, J. J. Appl. Biomed. 2008, 6, 117-129.

(5) Gillies, A. C. M.; Navarro, C.; Lowe, A. J.; Newton, A. C.; Hernández, M.; Wilson, J.; Cornelius, J. P. Heredity 1999, 83, 722-732.

(6) Eid, A. M. M.; Elmarzugi, N. A.; El-Enshasy, H. A. Int. J. Pharm. Pharm. Sci. 2013, 5, 47-53.

(7) Paritala, V.; Chiruvella, K. K.; Thammineni, C.; Ghanta, R. G.; 
Mohammed, A. Braz. J. Pharm. 2015, 25, 61-83.

(8) Pamplona, S.; Sá, P.; Lopes, D.; Costa, E.; Yamada, E.; e Silva, C.; Arruda, M.; Souza, J.; da Silva, M. Molecules 2015, 20, 18777-18788.

(9) Tong, W. Y.; Ang, S. N.; Darah, I.; Latiffah, Z. World J. Pharm. Pharm. Sci. 2014, 3, 121-132.

(10) Chen, Q.; Fung, K. Y.; Lau, Y. T.; Ng, K. M; Lau, D. T. W. Food Bioprod. Process. 2016, 98, 236-243.

(11) Onivogui, G.; Letsididi, R.; Diaby, M.; Wang, L; Song, Y. Asian Pac. J. Trop. Biomed. 2016, 6, 20-25.

(12) Siripatrawan, U.; Kaewklin, P. Food Hydrocolloid. 2018, 84, 125134.

(13) Panghal, M.; Singh, K.; Kadyan, S.; Chaudary, U.; Yadav, J. P. Burns 2015, 41, 812-819.

(14) Habermann, E.; Pereira, V. D. C.; Imatomi, M.; Pontes, F. C.;
Gualtieri, S. C. J. Braz. J. Bot. 2017, 40, 33-40

(15) Ertas, A.; Boga, M.; Gazioglu, I.; Yesil, Y.; Hasimi, N.; Ozaslan, C.; Yilmaz, H.; Kaplan, M. Chiang Mai J. Sci. 2016, 43, 89-99.

(16) Pushparaj, S. P.; Nellore, J.; Balaraman, R. M.; Sekar, U.; Tippabathani, J. Artif. Cells Nanomed. Biotechnol. 2018, 46, 268-273.

(17) Adesanwo, J. K.; Ogundele, S. B.; Akinpelu, D. A.; McDonald, A. G. J. Explor. Res. Pharmacol. 2017, 2, 67-77.

Received September 12, 2018

Revised October 8, 2018 Accepted October 9, 2018 